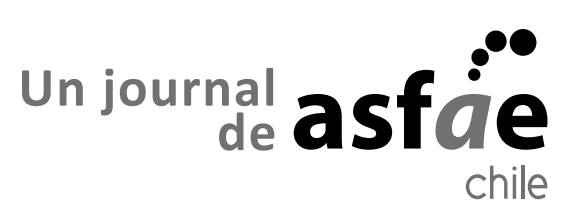

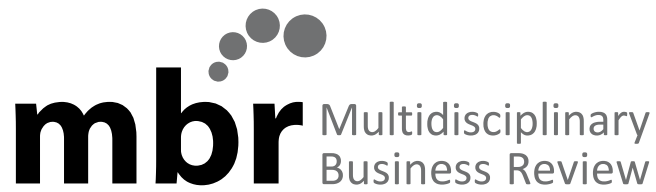

\section{INTER-CULTURAL COMPETENCY IN INTERNATIONAL LOCALS AND THEIR PERFORMANCE}

\author{
COMPETENCIA INTERCULTURAL Y DESEMPEÑO EN EMPLEADOS LOCALES \\ CON CONTACTOS INTERNACIONALES
}

\author{
Leonardo Liberman ${ }^{a}$ David Kimber Camussetti ${ }^{b}$ \\ Classification: Empirical paper - research \\ Received: September 14, 2020 / Revised: January 15, 2021 / Accepted: January 29, 2021
}

\begin{abstract}
This paper examines the relationship between intercultural competencies and performance in "international locals", defined as employees who, albeit not formally appointed to any international position, are regularly exposed to different types of intercultural interactions. From a sample of 258 employees of a multinational company, we selected a sub-group of 94 international locals, and examined the effect of ethnocentrism (ET), cultural intelligence (CQ) and emotional intelligence (EQ) on their performance, utilizing multiple regression analysis. The results show that the higher levels of CQ and/or EQ, the better the performance of international locals. Evidence also indicates that EQ interacts with CQ, triggering or enhancing the effect on performance. Finally, ET does not have any effect on the performance of international locals. The research implies that EQ and CQ are essential for performance in international business situations, and that international locals, who are continually exposed to regular intercultural interactions, need to focus on developing these two competencies. By assessing and helping international locals to develop higher EQ and CQ, organizations can ensure that they have enthusiastic and perseverant employees, who enjoy intercultural interactions, and can contribute to develop competitive advantages and capabilities.
\end{abstract}

Keywords: Intercultural competencies, cultural intelligence, performance, emotional intelligence, ethnocentrism, international locals.

\section{Resumen}

Este artículo examina la relación entre las competencias interculturales y el desempeño de los "locales internacionales", definidos como empleados que, aunque no están asignados formalmente a una posición internacional, están regularmente expuestos a diferentes tipos de interacciones interculturales. De una muestra de 258 empleados de una multinacional, seleccionamos un subgrupo de 94 "locales internacionales", y examinamos el efecto del etnocentrismo (ET), la inteligencia cultural (CQ) y la inteligencia emocional (EQ) en su desempeño por medio de un análisis de regresión múltiple. Los resultados muestran que a mayores niveles de CQ o EQ, mejor es el desempeño de los "locales internacionales". La evidencia también indica que EQ interactúa con CQ, incrementando el efecto en desempeño. Finalmente, ET no tiene ningún efecto en el desempeño de este grupo. La investigación concluye que EQ y CQ son esenciales para el desempeño en situaciones de negocios internacionales, y que los "locales internacionales", quienes están de manera continua expuestos a interacciones interculturales, necesitan centrarse en desarrollar estas dos competencias. A través de evaluar y ayudar a los "locales internacionales" a desarrollar EQ y CQ más altas,

a Libens R\&D, Santiago, Chile. ORCiD: 0000-0001-7992-4449. Email: info@libens.cl

b Faculty of Business and Economics, Universidad de Los Andes, Santiago, Chile. ORCiD: 0000-0002-3006-9231. Email: dkimber@uandes.cl 
las organizaciones pueden asegurarse de contar con empleados entusiastas y perseverantes que disfrutan las interacciones interculturales y que pueden contribuir a desarrollar ventajas competitivas y capacidades estratégicas.

Palabras clave: competencias interculturales, inteligencia cultural, desempeño, inteligencia emocional, etnocentrismo, locales internacionales.

\section{Introduction}

Advancing knowledge about the effects of intercultural competencies on the performance of international employees is fundamental for today's businesses (Thomas et al., 2015). Given the increased complexity and diversity of offshore operations, employees at any level need more than ever to develop their intercultural competencies if they are to be successful in their tasks (Bird et al., 2010).

As businesses continue to span national borders, employees at all levels are becoming involved in regular and deeper intercultural interactions with overseas customers, suppliers, employees and stakeholders (Alon \& Higgins, 2005). More than ever, local regular employees are exposed to unfamiliar cultures and culturally different workforces and stakeholders (Moon, 2010). This has made attributes like low ethnocentrism (ET) and competencies like cultural intelligence (CQ) and emotional intelligence (EQ) essential for virtually everyone facing international situations (Alon \& Higgins, 2005). The lack of such competencies derives on errors, conflicts (Black et al., 1991; Caliguri, 2000; Gabel et al., 2005; Moon, 2010; Takeuchi et al., 2002), hurdles and complexities that can stay undetected for a long time. This can be a source of continuous important losses (Brett et al., 2006; Gunkel et al., 2015) that could otherwise have been avoided from the beginning. On the contrary, if these competencies are assessed and developed early on, intercultural interactions will be successful, and employee performance may improve along with the business as a whole.

Accordingly, this study focuses on the intercultural competencies of "international locals" (ILs). We define ILs as domestic employees who have not been formally appointed to an international position but are frequently exposed to intercultural interactions to perform their jobs. ILs include employees at any level of the firm such as local technicians, professionals, administrative, managers and operative staff, who report regular intercultural contacts. These contacts can be face-to-face with members from other cultures (e.g. visiting international customers, suppliers, migrant workers, or expatriate colleagues) or remotely through voice, text or video systems.

Much of the intercultural research asserts that there are crucial attitudes and capabilities that are essential to perform well interculturally. As above-mentioned, CQ, EQ, and lower ET are essential for virtually everyone facing international situations (Caligiuri \& Tarique, 2012; Maznevski \& DiStefano, 2000). Therefore, this study focuses on these essential capabilities and aims to examine how levels of ET, CQ, and EQ influence the performance of this particular group of employees. For this purpose, we assess the performance of ILs in relation to their actual degree of ET, and their levels of CA and EQ. Furthermore, since studies suggest that there is a potential interaction between EQ and CQ, we test this combined effect on the performance of ILs (Gelfand et al., 2008).

In contrast to the traditional focus on expatriate assignments (Van Bakel et al., 2014) or global leaders (Adler, 1997; Beechler \& Javidan, 2007; Caligiuri \& Tarique, 2009; McCall \& Hollenbeck, 2002; Mendenhall et al., 2008), in this study we look at employees that live and work in their home country, but in their domestic roles are exposed to intercultural contacts or non-conventional international experiences (Suutari et al., 2013).

The attention to ET, CQ, EQ and performance on ILs (Gelfand et al., 2008) is an extremely relevant topic for the field due to three reasons. First, given the spread use of remote communication and massive movement of people across national frontiers, local employees are today, by default, exposed to intercultural encounters (Alon \& Higgins, 2005). These employees perform multiple and complementary tasks that in practice call for special competencies such as ET, CQ, and EQ. Although without an explicit assignment, these intercultural contacts are critical for the success of international operations since they support transactions and exchanges with important international stakeholders from international firms (Andresen \& Bergdolt, 2017; Johnson et al., 2006).

Second, although ILs represent a significant proportion of the domestic workforce in international companies, this type of employee has received little attention. In fact, scarce literature is found concerning intercultural competencies and performance of ILs. As it goes unnoticed and unendorsed, few researchers have conducted empirical studies assessing ILs performance in relation to their intercultural competencies. A lot of emphasis in the literature has been placed on the measurement and development of competencies of employees that travel away from their home country under a formal interna- 
tional assignment (Adler, 1997; Beechler \& Javidan 2007; Caligiuri \& Tarique, 2009; McCall \& Hollenbeck, 2002; McNulty \& Brewster, 2016; Mendenhall et al., 2008). Hence, further research is warranted, as we know very little about ILs competencies, failure or success in relation to their intercultural interactions.

Third, most of the effort and resources of firms are commonly concentrated in developing intercultural competencies on formally appointed international assignees (Mendenhall et al., 2008) and expatriates (Adler, 1997; McCall \& Hollenbeck, 2002). Nevertheless, there is little awareness and attention on domestic employees that enter into frequent intercultural contacts to perform their jobs. Therefore, we contend that the study of competencies of ILs and their performance will inform and motivate business practitioners to recognize, measure, and develop their intercultural competencies and the effects of these on performance.

\section{Theoretical Background}

\section{Ethnocentrism}

Intercultural competency is defined as the capacity to function successfully in a different culture (Dinges \& Baldwin, 1996; Gertsen, 1990). This involves cognitive, affective and behavioural capabilities (Chen \& Starosta, 1996) that are rooted in stable competencies, personality abilities or predispositions (Bird et al., 2010). Among these predispositions and abilities, ET has been amply studied (Neuliep et al., 2005) and a considerable body of research can be found on the nature and characteristics of ethnocentrism and its effect on performance of employees. ET is defined as "a view in which one's own group is the centre of everything, and all others are scaled and rated with reference to it" (Sumner, 1906, p. 13) and includes an inflexible in-group out-group distinction that comprises antagonistic and stereotyped attitudes and behaviours concerning out-groups (Adorno et al., 1950; Michailova et al., 2017). ET is, hence, characterized by high positivity in attitudes and assessments towards in-group relations and attributes and a high negativity towards out-groups. This pattern of biased perception and attitudes would predispose individuals to evaluate and behave affirmatively towards their own group and disapprovingly towards those that are considered different from their own group.

Intercultural research suggests that ET has a negative effect on interpersonal perceptions within the organization and is harmful to the development and maintenance of intercultural interactions (Caligiuri \& Tarique, 2012). In this regard, ET attitudes have been found to be negatively associated with social attraction, competence, character and hiring recommendations, and has been studied in terms of its influence on credibility, attraction and effectiveness in the manager-subordinate relationship (Adorno et al., 1950; Neuliep et al., 2005).

A low level of ET has also been found to be associated with intercultural absorption of knowledge (Kayes et al., 2005), and is considered an indicator of central skills in global leaders (Maznevski \& DiStefano, 2000). Besides, Thomas (1996) found that ethnocentrism is a barrier to effective intercultural interactions and that assignees higher on ET tend to experience more problems while adjusting to foreign environments. In the same line, Caligiuri and Tarique (2012) found that a lower level of ET is one of the characteristics that strongly predicts performance among expatriate employees (Shaffer et al., 2006). In addition, Thomas et al. (2015) measured ethnocentrism in 3526 respondents from 14 countries. They found that ethnocentrism is negatively related to both CQ and international exposure. In addition, with reference to non-expatriate employees, research shows that host employees tend to develop naturally strong ET attitudes (Florkowski \& Fogel, 1999; Templer, 2010) and those ethnocentric stances hamper the effectiveness of work interactions and exchanges (Banai, 1992; Zeira \& Banai, 1981). In this respect, Florkowski and Fogel (1999) show that local employees with ET attitudes tend to delay the guest expatriate adjustment and their overall level of commitment to the host operations.

Overall, literature asserts the negative effects of ET on both, employees that go abroad and those that remain at home, but have to interact interculturally (Caligiuri \& Tarique, 2012; Florkowski \& Fogel,1999; Kayes et al., 2005; Maznevski \& DiStefano, 2000; Michailova et al., 2017). Based on this evidence, it is not unreasonable to expect that ILs with higher levels of ET will show lower levels of attainment in their regular intercultural contacts and thus in their general job performance. We expect, in this case, that higher levels of ET will predispose domestic employees negatively towards outgroup members, resulting in poorer intercultural interactions and outcomes, and thus performance at work. Conversely, we expect that lower levels of ET in international locals will be related to higher performance in their roles. We contend that lower levels of ethnocentrism will enable more positive attitudes and behaviours towards outgroup members, favouring the intercultural interaction and thus their performance. Hence, our first hypothesis is:

H1: Ethnocentrism will be negatively associated with the performance of ILs. 


\section{Cultural intelligence}

Cultural intelligence (CQ) is the individual's ability to effectively behave and manage interactions in culturally heterogeneous situations (Earley, 2002; Li, 2020). It is a particular form of intelligence different from general, emotional and social intelligence (Earley \& Ang, 2003; Thomas et al., 2008), and that corresponds to cognitive structures and processes influencing intercultural effectiveness (Thomas et al., 2015).

CQ focuses on intercultural settings and refers to the individual's capacity to understand and appropriately deal with situations characterized by cultural diversity (Ang \& Van Dyne, 2008), and to adapt effectively to a new cultural context (Earley, 2002). In other words, CQ is a compound of abilities, which allow individuals to interact effectively with people that are culturally different (Thomas et al., 2015).

Accordingly, CQ is conceptualized as a second-order factor with four different facets: cognitive, metacognitive, motivational and behavioural. These four dimensions make up the overall construct CQ (Law et al., 1998) and although distinctive capabilities, taken together point to a general CQ (Ang et al., 2007). Lee and Sukoco (2010) has assessed the four dimensions of CQ and confirmed the construct as a second-order factor.

Cognitive CQ refers to the cultural knowledge about similarities and differences with respect to other cultures that a person has acquired through education and experience (Ang \& Van Dyne, 2008). Metacognitive $\mathrm{CQ}$ involves the mental processes through which cultural knowledge is acquired, including the questioning of assumptions and mental adjustment to relevant experiences (Ang \& Van Dyne, 2008). Motivational CQ is related to the drive to engage in culturally diverse interactions (Crowne, 2006; Earley, 2002), while behavioural CQ is the ability to acquire or adapt behaviour in international contacts and respond appropriately (Ang \& Van Dyne, 2008).

There have been numerous studies investigating the relationship between CQ, cultural adaptation and effectiveness (Lovvorn \& Chen, 2011). In a study of global professionals in Singapore, Templer et al., (2006) analysed the relationship between motivational CQ and three types of cross-cultural adjustment: general, work, and interaction adjustment. They found that motivational CQ was significantly related to these three variables, and those employees with a high motivational CQ tended to adjust better to work, life and social demands in foreign environments. Ang et al. (2007) found evidence supporting the validity of CQ over general intelligence, EQ and other variables, when explaining cultural adapta- tion. They found that, when adding CQ to the equation, the explained variance of cultural adaptation increased by $4 \%$ in a sample of US undergraduates and by $3 \%$ in a sample of undergraduates from Singapore. In addition, Lee and Sukoco (2010) examined the impact of CQ and cultural effectiveness on the performance of employees working for a Taiwanese multinational company. They found that CQ had a positive significant effect on cultural adjustment and that cultural adjustment and cultural effectiveness mediated the relationship between CQ and performance.

Altogether, empirical evidence shows a clear relationship between CQ and cultural effectiveness (Ang et al.,2007; Lee \& Sukoco, 2010; Lovvorn \& Chen, 2011; Templer et al., 2006; Ward et al., 2011). Therefore, we could speculate that higher levels of CQ will help ILs to be effective in their intercultural contact, affecting in some proportion, their overall performance at work. On the contrary, lower levels of CQ in ILs will limit their capacity to deal effectively in these intercultural situations. This may also be reflected negatively on their performance. Then, based on the empirical evidence presented above, we suggest that CQ will be a significant predictor of performance on ILs, leading us to propose that:

H2: CQ will be positively associated with the performance of international locals.

\section{Emotional intelligence}

Emotions are responses to changes in the relationship between the individual and the environment (Mayer et al., 2008) that have a positive or negative meaning for the individual (Salovey \& Mayer, 1990). Emotional intelligence (EQ) is a set of mental abilities that allow individuals to monitor their own and others' emotions, to differentiate them and to use the information to guide thinking and action (Rockstuhl et al., 2011; Salovey \& Mayer, 1990). EQ includes the capacity to perceive, assess and express emotions accurately and to facilitate thinking. It also involves the ability to understand emotions and to regulate them to promote emotional and intellectual growth (Mayer \& Salovey, 1997). EQ can be divided into four branches ranging from more basic to more advanced psychological processes (Mayer \& Salovey, 1997).

Firstly, perception, appraisal and expression of emotions, which are related to the accuracy with which individuals can identify emotions and emotional content in them and in others. This branch considers the ability to identify one's own emotions as well as the emotions of others. It also includes the ability to express emotions 
accurately and express needs related to those feelings (Mayer \& Salovey, 1997). Secondly, emotional facilitation of thinking concerns the emotions acting on the intellect and consider emotional events that assist intellectual processing (Mayer \& Salovey, 1997). Thirdly, understanding and analysing emotions relates to the ability to understand and use emotional knowledge. This capacity includes the ability to capture the meanings of emotions in relationships, understanding complex, contradictory emotions, and the ability to recognize sequences of emotions (Mayer \& Salovey, 1997). Finally, reflective regulation of emotions is related to the conscious regulation of emotions in order to enhance emotional and intellectual development (Mayer \& Salovey, 1997).

EQ improves individuals' social interactions because it enables them to identify and understand emotions in themselves and others, to regulate and manage emotions in order to make better decisions and to use all these processes to perform well and attain effective results. Given that cognitive ability accounts for almost $25 \%$ of the variance in job performance (Conte, 2005; Mayer et al., 2008), EQ is likely to be related to performance. In fact, Wong and Law (2002) found a positive relationship between EQ and performance in a sample of employees from a university. Besides, the correlation between performance and EQ in emotionally charged jobs was highly significant and positive. Van Rooy and Viswesvaran (2004) also found a positive correlation between EQ and performance and that EQ predicted performance in various domains (employment, academic achievement, and life). Their research covered different countries, permitting generalization of the results. These authors concluded that EQ is a valuable predictor of performance and is a very relevant ability for expatriate managers in equipping them to address new cultural contexts.

Law et al. (2004) also found that EQ was positively associated to task performance, independently of whether EQ was measured self-reportedly or peer-reportedly. This led them to suggest that EQ might be a good predictor of job performance. Similarly, in a study of US Air Force recruiters, Bar-On (2006) found a significant correlation between EQ and occupational performance, suggesting that it is useful in identifying high and low performers, while, in a study with Korean flight attendants, Lee et al. (2013) concluded that EQ was related to service recovery.

Besides, Côté and Miners (2006) found a correlation of 0.32 between EQ and task performance among fulltime employees and a significant interaction between cognitive intelligence (IQ) and EQ in the prediction of task performance. They concluded that "the relationship between EQ and task performance becomes more posi- tive as IQ decreases" (Côté \& Miners, 2006, p. 15). In the same line, Rozell et al. (2006) also found a positive significant association between EQ and job performance, whereas Jadhav and Mulla (2010) found that EQ was significantly related to job performance among employees with a large number of interpersonal interactions.

As previous research shows, EQ is an important antecedent of job performance. Therefore, it is not unreasonable to expect that ILs with higher levels of EQ will show better performance at their work. Higher levels of EQ may help ILs to deal with tasks associated to their local roles. Conversely, we also expect that ILs scoring lower in EQ, will tend to perform lower in their positions. Hence, based on this empirical evidence, it is possible to hypothesize that:

H3: EQ will be positively associated with the performance of international locals.

\section{Emotional intelligence and Cultural intelligence}

Early scholars in the field have recognized that successful performance in international roles is attached to the concurrent effect of multiple intelligences such as EQ and CQ (Alon \& Higgins, 2005). This means that to perform an international task, individuals activate multiple behavioural resources and capabilities at same time. In this regard, research has shown that CQ and EQ are different types of competencies that act complementarily in the performance of tasks (Gelfand et al., 2008). EQ is culturally specific, and it is not directly related to cross-cultural interactions, but CQ is (Earley \& Ang, 2003). Hence, the concurrent assessment of these capabilities is necessary to better understand their overall effect on performance. In this regard, Moon, (2010) found that CQ is related to EQ construct across its different facets. The author presented insightful empirical evidence that a relationship exists between CQ and EQ and that although they are separate concepts, they are closely interrelated. Moreover, Thomas et al. (2015) assessed EQ in relation to their conceptualization of CQ and found that these constructs are significantly intercorrelated. Higher levels of EQ were associated with higher levels of CQ in their sample, confirming that these capabilities, although different, tend to vary together.

In this area, Lee (2010) contends that multiple intelligences are usually studied separately, and it is necessary to understand how they interact affecting the performance of individuals. The author concluded that CQ helps people to understand why they think and behave differently, and that EQ lets them manage their emotions while interacting interculturally (Lee, 2010). Furthermore, EQ has 
been found to be related to general social competence (Earley \& Ang, 2003), an attribute that is fundamental to CQ. People with higher EQ tend to show improved social performance and are better at dealing with the emotional reactions of others. In a similar line, several studies in the field support the idea that employees higher in EQ manage their emotions better (accurately and adaptively), when engaging interculturally (Earley \& Ang, 2003; Moon, 2010). In this sense, EQ should help ILs to better regulate emotional responses when entering into contact with people from different cultures. In this regard, Gelfand et al. (2008) anticipated early on that CQ is a construct with high potential for interaction with other constructs and intelligences, like EQ.

Considering the interrelationship between EQ and CQ (Moon, 2010; Thomas et al., 2015) the ample consensus that EQ helps in intercultural encounters (Moon, 2010) and that it there is a potential interaction between these (Côté \& Miners, 2006), we expect that varying levels of EQ and CQ will interact, affecting the performance of international locals. Specifically, we propose that for the case of ILs, the presence of higher levels of EQ will enhance the effect that CQ has on their performance. Therefore, we propose the following hypothesis:

H4: EQ has a positive moderator effect on the relationship between $\mathrm{CQ}$ and performance.

\section{Methodology}

\section{Sampling}

After receiving approval from headquarters, 955 employees from a multinational company were contacted by e-mail. The company specializes in worldwide consulting and information technology services and operates in the Latin-American region. The sample came from employees working in Argentina, Brazil, Chile, Colombia, Mexico and Uruguay.

Employees received a link to an online questionnaire, obtaining a final sample of 258 employees after three waves of reminders; a response rate of around $27 \%$. All the respondents were asked about the frequency of their contact with people from countries other than their own. They were also asked about how often they interacted internationally by any means: daily, 2-3 times a week, once a week, 2-3 times a month, once a month, or never. All those employees who reported having at least three regular international contacts a week were classified as international locals, providing 106 usable cases. However, 12 cases were subsequently excluded since they were expatriates or immigrants, obtaining a final sample of 94 individuals.

Men accounted for $62.5 \%$ of this final sample and the ages ranged from 22 to 60 years (mean: 36.18, s.d.: 7.7). The international locals had an average 13.9 years of work experience and had been in their current job for an average of 4.5 years. The vast majority had a university degree (88\%) and $71.9 \%$ were line managers, $24.2 \%$ held professional/technical or analyst positions, and $3.9 \%$ were senior managers.

\section{Instruments}

Ethnocentrism was measured using the generalized ethnocentrism scale (GENE) developed by Neuliep and McCroskey (1997). GENE is based on a 22-item questionnaire answered according to a Likert scale of 1 (strongly disagree) to 5 (strongly agree). It includes items like "lifestyles in other cultures are not as valid as those in my culture" and "other cultures are smart to look up to my culture". A number of studies have demonstrated the questionnaire's reliability and validity (Chen, 2010; Dong et al., 2008; Neuliep, 2002). For the purposes of this study, only the ten items with the highest factor loadings were used out of the 15 used for scoring ethnocentrism in the revised GENE scale (Neuliep, 2002; Neuliep \& McCroskey, 1997).

CQ was measured using the CQS, a scale developed by Van Dyne et al. (2008). The CQS is a 20-item, 7-point Likert-type scale, ranging from 1 (strongly disagree) to 7 (strongly agree), where a higher score indicates a higher CQ. It includes items like "I am conscious of the cultural knowledge I use when interacting with people with different cultural backgrounds" and "I use pause and silence differently to suit different cross-cultural situations". Its structure has been validated in previous research (Ang et al., 2007; Crowne, 2006; Ward et al., 2009).

Following an ability-based approach to EQ, we decided to use the WLEIS scale to measure the employees' level of emotional intelligence. This scale provides a short, practical and empirically valid measure of EQ (Law et al., 2004; Wong \& Law, 2002). The WLEIS is a 20 -item, 7-point Likert-type scale, ranging from 1 (strongly disagree) to 7 (strongly agree), where a higher score indicates a higher EQ. It includes items like "I am a good observer of others" emotions" and "I am able to control my temper so that I can handle difficulties rationally".

Regarding performance, we measured the employees' perception of their job performance. Based on Giacobbe et al. (2006) and Law et al. (2004), we designed a threeitem 7-point Likert-type scale about performance, ranging 
from 1 (poor) to 7 (outstanding). The individuals had to rate their performance over the last 12 months from three perspectives: in general, relative to their peers, and relative to their goals.

Table 1 shows mean, standard deviation, Pearson correlations, and Cronbach alphas for all these instruments. Regarding internal consistency, all scales showed satisfactory alphas of above 0.7 (Nunnally \& Bernstein, 1994). In addition, correlations show a negative relationship between ethnocentrism and performance $(r=-0.19$, $\mathrm{p}<0.05)$ and a positive relationship of CQ and EQ to performance $(\mathrm{r}=0.31, \mathrm{p}<0.01$, and $\mathrm{r}=0.39, \mathrm{p}<0.01$, respectively). However, although significant, the association between ethnocentrism and performance is not very high, with ethnocentrism explaining only $3.6 \%$ of the variance of the performance variable.

Table 1. Internal consistencies of the sub-scales and zero order correlations between the dependent and independent variables

\begin{tabular}{lcccccc}
\hline \multicolumn{1}{c}{ Variables } & Mean & S.D. & $\mathbf{1}$ & $\mathbf{2}$ & $\mathbf{3}$ & Alpha \\
\hline 1. Performance & 5.70 & 0.84 & & & & 0.90 \\
2. CQ & 5.09 & 0.94 & $0.31^{\mathrm{a}}$ & & & 0.94 \\
3. Ethnocentrism & 1.59 & 0.72 & $-0.19^{\mathrm{a}}$ & -0.15 & & 0.90 \\
4. EQ & 5.60 & 90 & $0.39^{\mathrm{a}}$ & $0.59^{\mathrm{a}}$ & $-0.20^{\mathrm{a}}$ & 0.96 \\
\hline
\end{tabular}

a Significant correlations, $\mathrm{p}<0.05$.

For the purpose of this study, we considered CQ as a latent construct formed by its facets (Ang et al., 2007; Law et al., 1998; Lee \& Sukoco, 2010). In a CFA with $\mathrm{CQ}$ as a second-order construct, we found a good fit $\chi^{2}(166)=235.9, \mathrm{p}<0.05, \mathrm{RMSEA}=0.054, \mathrm{CFI}=0.95$, $\mathrm{SRMR}=0.07, \chi^{2} / \mathrm{df}=1.42$. Similarly, we also considered EQ as a second-order factor. The WLEIS was constructed based on the definition of Mayer and Salovey (1997), while Whitman et al. (2009) confirmed early on the presence of a second-order structure. In a CFA with EQ as a second-order construct, we found a good fit $\chi^{2}(100)=$ 143.01, $\mathrm{p}<0.05$, RMSEA $=0.054, \mathrm{CFI}=0.97$, SRMR $=$ $0.053, \chi^{2} / \mathrm{df}=1.43$. Both cases show indexes below the common thresholds considered by the literature (Bagozzi \& Yi, 1988; Hu \& Bentler, 1998; Tay \& Jebb, 2017).

Given the design and scope of this approach, we have to take several measures to control for potential common method bias and validity issues in our study (Podsakoff et al., 2003). To minimize apprehension and social desirability bias, we guaranteed anonymity to all respondents and motivated them to respond openly, telling them that there were no right or wrong answers in the questionnaires. In addition, the design of the questionnaires followed the recommendations of Aaker et al. (2010). In the case of multiple scales, the categories were displayed randomly. Furthermore, the sequence of the questions and items was pre-tested in order to prevent the order bias (Podsakoff et al., 2003). Finally, when the respondents answered a question, they could not go back and change their answers, meaning that they could not edit their prior answers to reach consistency with later items.

Additional to the procedure followed in the questionnaire, we conducted a Harman one-factor test, including all the items from the CQ, EQ and GENE scales in a principal component factor analysis (Podsakoff \& Organ, 1986; Podsakoff et al., 2003). We did not find a one factor solution as it only accounted for $37.58 \%$ of the total variance. Therefore, it is possible to state that there is no presence of common method variance.

Finally, in order to guard against the effects of non-related factors, gender, age, educational level and level within the company were considered as control variables. Educational level was coded from 1 (elementary school) to 3 (higher education). Hierarchical level within the company was coded from 1 (operative) to 4 (senior manager). However, no respondent in the study belonged to level 1. Finally, the respondents were asked to register both their birth year (to obtain their age) and their gender.

\section{Results}

In order to answer our hypotheses, we conducted a multiple regression analysis examining the relationship between individual performance, CQ, EQ and ethnocentrism. We used the ordinary least squares (OLS) methodology where the dependent variable was performance and the independent variables were a set of control variables, $C Q, E Q$, ethnocentrism and an interaction between CQ and EQ.

Our initial model did not satisfy the OLS homoscedasticity assumption with a Breutsch-Pagan test, indicating heteroscedasticity $\left(\chi^{2}=6.48 ; p=0.0109\right)$. In addition, there was a multicollinearity problem among CQ, EQ and the interaction, confirmed by a VIF for CQ and EQ above 10 and for the interaction above 30 (Wooldridge, 2009). Both problems are typical when estimating moderated regressions with continuous data (Cohen \& Cohen, 1983; Echambadi \& Hess, 2007).

In order to control multicollinearity and the potential effect of interaction without affecting the significance of EQ and CQ, we standardized the variables according to Marquandt and Snee (1975). This procedure was considered useful and valid in line with our hypotheses (Kim, 1999; Neter et al., 1985), allowing us to determine the direction of the effects of the variables being studied. Additionally, the model supported homoscedasticity (Breutsch-Pagan test, $\chi^{2}=2.87 ; \mathrm{p}=0.09$; and White 
test $\chi^{2}=93 ; p=0.4512$ ). Table 2 shows the results for our final multiple regression model. It observes that the model is significant $(\mathrm{F}(9.83)=4.151, \mathrm{p}<0.001)$ with an adjusted $\mathrm{R}^{2}$ of $31 \%$.

Table 2. Multiple regression analysis with performance as the dependent variable

\begin{tabular}{lcccc}
\hline Variable & $\boldsymbol{B}$ & $\boldsymbol{S E} \boldsymbol{B}$ & $\boldsymbol{p}$-value & Adj- $^{2} \mathbf{2} \mathbf{0 . 3 0 7}$ \\
\hline Age & 0.001 & 0.012 & 0.908 & \\
Gender & -0.142 & 0.190 & 0.457 & \\
Educational level & -0.355 & 0.283 & 0.214 & \\
Company level & 0.344 & 0.243 & 0.160 \\
Ethnocentrism & -0.024 & 0.093 & -0.799 \\
CQ & $0.266^{\mathrm{a}}$ & 0.123 & 0.034 \\
EQ & $0.492^{\mathrm{b}}$ & 0.124 & 0.000 \\
CQ x EQ & $0.242^{\mathrm{b}}$ & 0.052 & 0.000 \\
\hline
\end{tabular}

${ }^{\text {a }}$ Significant at $5 \%,{ }^{\text {b }}$ Significant at $1 \%$.

According to the results, three of the independent variables significantly predict individual job performance, namely CQ $(B=0.266, \mathrm{p}<0.05)$, EQ $(B=0.492$, $\mathrm{p}<0.001)$ and the interaction between CQ and EQ $(B=0.242, \mathrm{p}<0.001)$. Consequently, Hypothesis 1 , which states that ET will be negatively associated with the performance of ILs, is not supported by the evidence $(\beta=-0.024, \mathrm{p}>0.05)$.

Regarding Hypothesis 2, which states that CQ will be positively associated with the performance of ILs, is supported by the evidence. CQ is significantly positively related to individual job performance. Concerning Hypothesis 3, which states that EQ would significantly predict individual performance of ILs, results also supported it. EQ is significantly positively related to individual job performance. Therefore, we found that CQ and EQ are independently good predictors of ILs' job performance.

Finally, regarding Hypothesis 4, which states that EQ has a positive moderator effect on the relationship between CQ and performance, we found that the data also confirmed this effect. The coefficient associated to the moderator effect is positive and significant. As the data show, EQ and CQ tend to interact, affecting positively performance in international locals. Specifically, higher levels of EQ tend to strengthen the relationship between CQ and ILs job performance.

\section{Discussion}

The main purpose of this study was to examine the relationship between ET, EQ and CQ and the performance of international locals. Our fundamental premise was that, given their regular intercultural interactions, performance ought to be affected in terms of their individual attributes and competencies such as ET, CQ and EQ.

Concerning our first hypothesis which proposed that lower levels of ET in respondents would be associated with higher performance, we could not confirm it. Although we expected statistically negative relationship between these two variables, the effect was not noticeable, and the results showed that ET is not a predictor of performance on the sample of ILs. This can suggest that the negative influence of ET on performance (Chen, 2010; Dong et al., 2008; Neuliep, 2002) is weaker when there are higher levels of CQ and EQ. The negative in-group out-group inflexible distinction in international locals (Kayes et al., 2005; Neuliep et al., 2005) did not have an explicit influence on performance. We could argue that ET negative effects can be overridden or minimized by the development of EQ and CQ competence.

Furthermore, our second hypothesis which contended that a higher level of CQ would be a predictor of individual job performance in international locals is accepted. The analyses revealed a significant positive correlation between CQ and performance, and, more importantly, that CQ is a significant predictor of job performance in ILs. Therefore, we can conclude that CQ predicts the performance of ILs. Higher CQ will allow international locals to effectively behave and manage their interactions in culturally heterogeneous situations, contributing to their overall success in their jobs. This is consistent with early evidence regarding the relationship between CQ and work performance (Alon \& Higgins, 2005; Lovvorn \& Chen, 2011).

Additionally, our third hypothesis which stated that a higher level of EQ would be a predictor of individual job performance in international locals is also accepted. The analyses revealed a significant positive correlation between EQ and performance, and as in the case of CQ, EQ is also a predictor of job performance. These results are consistent with previous studies about EQ and performance (Côté \& Miners, 2006; Jadhav \& Mulla, 2010; Law et al., 2004; Lee et al., 2013; Rozell et al., 2006; Van Rooy \& Viswesvaran, 2004; Wong \& Law, 2002). Hence, EQ helps ILs to perceive, assess and express emotional reactions appropriately in their work. It may also assist ILs to understand foreign employees' emotional reactions and to regulate them appropriately.

Finally, out fourth hypothesis in this study stated that EQ would have a positive moderator effect on the relationship between CQ and performance of international locals. We stated that previous research has shown that EQ and CQ affect employee performance and we expected that the simultaneous effect of these two 
domains of competence would be positive on performance of ILs. Certainly, this interaction was found to be a significant positive predictor of performance in international locals, leading us to accept our fourth hypothesis. In other words, when an international local has a higher level of EQ, the increase in performance when CQ increases is larger than that for those people with a lower EQ. Thus, we can conclude that EQ enhances the positive effect of CQ on the performance of ILs. These findings are in line with the view that EQ and CQ are essential for performance in international business situations and that employees exposed to regular intercultural interactions need to focus on developing these two competencies.

\section{Conclusions}

Our results are interesting and relevant for four reasons. First, much of the literature states lower levels of ET are one of the characteristics that predict performance in expatriates (Caligiuri \& Tarique, 2012) and that is an important skill in global leaders (Maznevski \& DiStefano, 2000), in turn being an essential condition for performance in those cases. However, surprisingly, our findings do not confirm this suggestion; it seems that this deduction does not apply to ILs. In this respect, we posit that ILs have a dual interactive role as they deal with two distinct community of stakeholders: locals and internationals. To perform such a task effectively, ILs have to develop, maintain and switch across complex and sometimes contradictory attitudes, skills and competencies that are functional to their tasks. Among these include ET attitudes and behaviours.

In fact, ET has been found to have positive effects on what is regarded as in-group functioning and performance and social identity. ET provides an in-group positivity including comradeship, devotion, loyalty and cohesion to the in-group (Neuliep et al., 2005; Michailova et al., 2017). Such in-group positivity normally carries an out-group negativity, a sense of supremacy to any out-group and the willingness to protect the interests of the in-group against the out-group (Michailova et al., 2017). Using the concepts of Michailova et al. (2017), we suggest that the null effect of ET on ILs performance is given a prevalence of in-group positive bias over outgroup negativity. Higher levels of in-group positivity and lower levels of out-group negativity would explain the lack of adverse effect of ET on performance in ILs. To test this conjecture, it would be necessary to differentiate ET items that point to in-group positivity from those that point out-group negativity and verify whether ILs show a prevalence of in-group positivity over out-group negativity, or not.

Second, we find that although ILs represent a significant proportion of the domestic workforce in international companies, little attention in the literature has been given to the intercultural competencies of this group of employees. Only a few researchers have conducted empirical studies assessing their competencies in relation to their performance. Much emphasis in the literature has been placed on the measurement and development of competencies of employees that travel away from their home country under a formal international assignment (Adler, 1997; Beechler \& Javidan 2007; Caligiuri \& Tarique, 2009; McCall \& Hollenbeck, 2002; Mendenhall et al., 2008). Hence, further research is warranted, as we know very little about international locals' competencies, failure, or success in relation to their intercultural interactions.

Third, most of the effort and resources of firms are commonly concentrated on developing intercultural competencies in international assignees (Mendenhall et al., 2008) and expatriates (Adler, 1997; McCall \& Hollenbeck, 2002). Nevertheless, there is little awareness and attention on domestic employees that have frequent intercultural contacts in order to perform their jobs. We believe that the present study informs and helpfully motivates practitioners to recognize, measure, and develop intercultural competencies of ILs.

In conclusion, these findings indicate that CQ and EQ predict performance of international locals and that the presence of higher levels of EQ increase the effect of CQ on the performance of international locals. At this point, we should ask: Why do ILs require high levels of EQ and CQ to be successful in their jobs? We argue that ILs, who are exposed to frequent intercultural interactions, have to use a dual repertoire of behaviours to cope with a dual domain of interaction: local and international. In their jobs, ILs have to engage with other locals using local norms and approaches. At the same time, their role often requires them to interact with internationals, switching regularly to foreign repertoires of behaviour (customs, language, styles, norms, conventions, etc.). This alternating pattern across domains is not trivial and calls for complex perceptual, cognitive, affective and behavioural skills. In this context, we argue that EQ-related competencies help international locals to cope effectively in local interactions, while CQ-related competencies help them to perform better in their international interactions. Finally, EQ and CQ combined assist them in tasks where the domains of interaction overlap; for instance, in transferring knowledge, solving complex problems, or 
making complex decisions that involve local and international stakeholders simultaneously.

\section{Limitations and future research}

This study, just like any other, has some limitations. First, the current sample only represents the population in question. The study was conducted based on convenience sampling and it is not possible to assert that its findings can be generalised to a broader population. Nevertheless, the sample and outcomes can be taken as a rough approximation of behavioural patterns found in this domain.

Another limitation in this study regards the use of self-reported questionnaires where the respondents are the only source of predictor and criterion variables (Podsakoff et al., 2003). The use of these questions increases the risk of common method variance or systematic error variance shared among variables that are measured with the same source or method (Campbell \& Fiske, 1959). One of the errors is social desirability, including the presentation of the items and the context in which the items are placed. To minimize this effect, we introduced a procedural remedy: we randomized the presentation of items from the independent and dependent variables and we protected anonymity of the respondent. Nevertheless, we suggest that future studies search for multiple sources of data in order to better guard against common method variance errors.

Moreover, as with any cross-sectional study, the results of this study should be treated carefully. This type of design is subject to bias due to low response rates, misclassification and the occurrence of contextual, temporal and strange variables during the assessment. These are factors that cannot be controlled with a design like this and the only way to verify the findings of this study is by replicating them in different samples and in different contexts.

An additional limitation in this study is the final IL sample size. The final IL sample limited the possibilities to expand our analysis and assess the interrelation between facets of the constructs in the study. Hence, we suggest that future research assessing ET, CQ and EQ in internationals locals should involve larger samples. This way, it may be possible to examine the interrelationship between the subordinated facets across constructs in ILs.

In fact, given the design of this study and the sample size, we do not know how the particular facets of the CQ contribute more to performance in this group of employees. It would be interesting to examine this issue in a larger sample of international locals and verify the most critical facets for performance in these contexts; for instance; motivational CQ (Ward et al., 2009) or metacognitive CQ (Ward et al., 2011).

The sample comprised different levels of employees and managers. It can be claimed that these two categories are different types of ILs due to the complexity of their role (Reiche et al., 2009), implying different demands for intercultural competencies. Nevertheless, none of the ILs held global leader roles and we did not find any significant differences according to the hierarchical position of the respondents. In future studies, it would be interesting to measure the valence, intensity and complexity of the ILs' tasks in relation to EQ, CQ and performance.

In this respect, we believe that a genuine limitation of the sample resides in the fact that an important proportion of the respondents held executive positions. Employees in operational positions are also exposed to regular intercultural interactions in international companies and we believe that this category of employees should be better covered in future studies.

\section{Managerial implications}

Nowadays, intercultural interactions are part of the daily operations in most companies. These regular internal and/ or external exchanges and interactions pose challenges to employees and the company as a whole. Part of their success depends on effective daily handling of these discrete interactions between culturally different employees, customers, suppliers and stakeholders. By assessing and helping ILs to develop higher EQ and CQ, businesses can ensure that they have positive employees who enjoy these intercultural interactions and can contribute to the creation of competitive advantages and capabilities (Sabuhari et al., 2020). Assessment and development of these competencies might help recruitment processes for positions that informally involve frequent cross-cultural relationships. They can also help companies to identify the cultural environments that would be most appropriate for ILs and the interventions and training required to achieve the best adjustment, especially when soft skills training has a positive impact on individual performance (Deshpande \& Munshi, 2020). Finally, this knowledge provides insights about candidates and their capacity to adapt and perform in positions that demand high levels of intercultural interaction.

Companies need to create development policies that encourage employees at any level to appreciate, understand and deal effectively with international customers, suppliers, co-workers and stakeholders. Therefore, EQ should be included as being linked to CQ given that, according to this study, both competencies predict 
employees' performance in roles that entail intercultural interactions.

Successful interactions with people from different cultures, either face-to-face or electronically, is essential nowadays (Thomas et al., 2015). In line with the nature of business today, this field of research must broaden its focus on the understanding and development of the intercultural competencies of those locals who are frequently exposed to non-conventional international experiences. Given technological advances in communication, these interactions may, in the very near future, account for the largest proportion of the intercultural interactions that occur in international companies.

\section{References}

Aaker, D. A., Kumar, V., \& Day, G. S. (2010). Marketing research. Wiley.

Adler, N. J. (1997). Global leadership: Women leaders. Management International Review 37, 171-196.

Adorno, T. W., Frenkel-Brunswik, E., Levinson, D. J., \& Sanford, R. N. (1950). The authoritarian personality. Harper.

Alon, I., \& Higgins, J. M. (2005). Global leadership success through emotional and cultural intelligences. Business Horizons, 48(6), 501-512.

Andresen, M., \& Bergdolt, F. (2017). A systematic literature review on the definitions of global mindset and cultural intelligence - Merging two different research streams. The International Journal of Human Resource Management, 28(1), 170-195

Ang, S., \& Van Dyne, L. (2008). Conceptualization of cultural intelligence: Definition, distinctiveness, and nomological network. In S. Ang, \& L. Van Dyne (Eds.), Handbook of Cultural Intelligence: Theory, Measurement and Applications (pp. 3-15). Sharpe.

Ang, S., Van Dyne, L., Koh, C., Ng, K. Y., Templer, K. J., Tay, C., \& Chandrasekar, N. A. (2007). Cultural intelligence: Its measurement and effects on cultural judgment and decision-making, cultural adaptation and task performance. Management and Organization Review, 3(3), 335-371.

Bagozzi, R. P., \& Yi, Y. (1988). On the evaluation of structural equation models. Journal of the Academy of Marketing Science, 16(1), 74-94.

Banai, M. (1992). The ethnocentric staffing policy in multinational corporations: A self-fulfilling prophecy. International Journal of Human Resource Management, 3(3), 451-472.

Bar-On, R. (2006). The Bar-On model of emotional-social intelligence (ESI). Psicothema, 18, 13-25
Beechler, S., \& Javidan, M. (2007). Leading with a global mindset. In M. Javidan, R. M. Steers, \& M. A. Hitt, (Eds.), The global mindset: Advances in international management (vol. 19, pp. 131-169). Emerald Group Publishing Limited.

Bird, A., Mendenhall, M., Stevens, M. J., \& Oddou, G. (2010). Defining the content domain of intercultural competence for global leaders. Journal of Managerial Psychology, 25(8), 810-828.

Black, J. S., Mendenhall, M., \& Oddou, G. (1991). Toward a comprehensive model of international adjustment: An integration of multiple theoretical perspectives. Academy of Management Review, 16(2), 291-317.

Brett, J., Behfar, K., \& Kern, M. C. (2006). Managing multicultural teams. Harvard Business Review, 84(11), 84-91.

Caligiuri, P. M. (2000). Selecting expatriates for personality characteristics: A moderating effect of personality on the relationship between host national contact and cross-cultural adjustment. Management International Review, 40, 61-80.

Caligiuri, P., \& Tarique, I. (2009). Predicting effectiveness in global leadership activities. Journal of World Business. 44(3), 336-346.

Caligiuri, P., \& Tarique, I. (2012). Dynamic cross-cultural competencies and global leadership effectiveness. Journal of World Business, 47(4), 612-622.

Campbell, D. T., \& Fiske, D. W. (1959). Convergent and discriminant validation by the multitrait-multimethod matrix. Psychological Bulletin, 56(2), 81-105.

Chen, G. M. (2010). The impact of intercultural sensitivity on ethnocentrism and intercultural communication apprehension. Intercultural Communication Studies, 19(1), 1-9.

Chen, G. M., \& Starosta, W. J. (1996). Intercultural communication competence: A synthesis. In B. Burleson (Ed.), Communication Yearbook 19 (pp. 353-383). Sage.

Cohen, J., \& Cohen, P. (1983). Applied multiple regression/correlation analysis for the behavioral sciences (2nd ed.). Lawrence Erlbaum.

Côté, S., \& Miners, C. T. (2006). Emotional intelligence, cognitive intelligence, and job performance. Administrative Science Quarterly, 51(1), 1-28.

Conte, J. M. (2005). A review and critique of emotional intelligence measures. Journal of Organizational Behaviour, 26(4), 433-440.

Crowne, K. A. (2006). Examining the antecedents of cultural intelligence. In Widener University proceedings-AIB-Se (USA) Annual Meeting. Clearwater Beach, Florida. 
Deshpande, S., \& Munshi, M. M. (2020). The impact of soft skills training on the behavior and work performance of employees in service organizations. IUP Journal of Soft Skills, 14(1), 7-25

Dinges, N. G., \& Baldwin, K. D. (1996). Intercultural competence: A research perspective. In D. Landis \& R. S. Bhagat (Eds.), Handbook of Intercultural Training (pp. 106-123). Sage

Dong, Q., Day, K. D., \& Collaço, C. M. (2008). Overcoming ethnocentrism through developing intercultural communication sensitivity and multiculturalism. Human Communication, 11(1), 27-38.

Earley, P. C. (2002). Redefining interactions across cultures and organizations: Moving forward with cultural intelligence. Research in Organizational Behavior, 24, 271-299.

Earley, P. C., \& Ang, S., (2003). Cultural Intelligence: Individual interactions across cultures. Stanford University Press.

Echambadi, R., \& Hess, J. D. (2007). Mean-Centering does not alleviate collinearity problems in moderated multiple regression models. Marketing Science, 26(3), 438-445.

Florkowski, G. W., \& Fogel, D. S. (1999). Expatriate adjustment and commitment: The role of host-unit treatment. International Journal of Human Resource Management, 10(5), 783-807.

Gabel, R. S., Dolan, S. L., \& Cerdin, J. L. (2005). Emotional intelligence as predictor of cultural adjustment for success in global assignments. Career Development International, 10(5), 375-95.

Gelfand, M. J., Imai, L., \& Fehr, R. (2008). Thinking intelligently about cultural intelligence: The road ahead. In S. Ang, \& L. Van Dyne (Eds.), Handbook of Cultural Intelligence (pp. 375-388). Sharpe.

Gertsen, M. (1990). Intercultural competence and expatriates. The International Journal of Human Resource Management, 1(3), 341-362.

Giacobbe, R. W., Jackson Jr, D. W., Crosby, L. A., \& Bridges, C. M. (2006). A contingency approach to adaptive selling behavior and sales performance: Selling situations and salesperson characteristics. Journal of Personal Selling \& Sales Management, 26(2), 115-142.

Gunkel, M., Schlaegel, C., Rossteutscher, T., \& Wolff, B. (2015). The human aspect of cross-border acquisition outcomes: The role of management practices, employee emotions, and national culture. International Business Review, 24(3), 394-408.

Hu, L., \& Bentler, P. M. (1998). Fit indices in covariance structure modeling: Sensitivity to underparameterized model misspecification. Psychological Methods, 3(4), 424-453.
Jadhav, S., \& Mulla, Z. R. (2010). Do emotionally intelligent people do well in all jobs? Exploring the moderating role of inter-personal interaction. Vision, 14(4), 247-254.

Johnson, J. P., Lenartowicz, T., \& Apud, S. (2006). Cross-cultural competence in international business: Toward a definition and a model. Journal of International Business Studies, 37, 525-543.

Kayes, D. C., Kayes, A. B., \& Yamazaki, Y. (2005). Essential competencies for cross-cultural knowledge absorption. Journal of Managerial Psychology, 20(7), 578-589.

Kim, D. (1999). A standardization technique to reduce the problem of multicollinearity in polynomial regression analysis. Proceedings of the 52th International Statistical Institute ISI Session. https://www.stat.fi/ isi99/proceedings/arkisto/varasto/kim_0574.pdf

Law, K. S., Wong, C. S., \& Mobley, W. M. (1998). Toward a taxonomy of multidimensional constructs. Academy of Management Review, 23(4), 741-755.

Law, K. S., Wong, C. S., \& Song, L. J. (2004). The construct and criterion validity of emotional intelligence and its potential utility for management studies. Journal of Applied Psychology, 89(3), 483-496.

Lee, J. H., Kim, M. S., \& Jeon, A. (2013). The effects of emotional intelligence on service recovery and organizational loyalty: A case of flight attendants of South Korean airlines. Service Business, 7(4), 665-686.

Lee, L. Y. (2010). Multiple intelligences and the success of expatriation: The roles of contingency variables. African Journal of Business Management, 4(17), 3793-3804.

Lee, L. Y., \& Sukoco, B. M. (2010). The effects of cultural intelligence on expatriate performance: The moderating effects of international experience. The International Journal of Human Resource Management, 21(7), 963-981.

Li, M. (2020). An examination of two major constructs of cross-cultural competence: Cultural intelligence and intercultural competence. Personality and Individual Differences, 164, 1-6.

Lovvorn, A. S., \& Chen, J. S. (2011). Developing a global mindset: The relationship between an international assignment and cultural intelligence. International Journal of Business and Social Science, 2(9), 275-183.

Marquardt, D. W., \& Snee, R. D. (1975). Ridge regression in practice. The American Statistician, 29, 3-20.

Mayer, J. D., \& Salovey, P. (1997). What is emotional intelligence? In P. Salovey \& D. Sluyter (Eds.), Emotional development and emotional intelligence: Implications for educators (pp. 3-31). Basic Books. 
Mayer, J. D., Salovey, P., \& Caruso, D. R. (2008). Emotional intelligence: New ability or eclectic traits? American Psychologist, 63(6), 503-511.

Maznevski, M. L., \& DiStefano, J. J. (2000). Global leaders are team players: Developing global leaders through membership on global teams. Human Resource Management, 39(2), 195-208.

McCall, M. W., \& Hollenbeck, G. P. (2002). Developing global executives: The lessons

of international experience. Harvard Business School Press.

McNulty, Y., \& Brewster C. (2016). The concept of business expatriates. In Y. McNulty \& J. Selmer (Eds.), Research Handbook of Expatriates (pp. 21-60). Edward Elgar Publishing.

Mendenhall, M. E., Osland, J. S., Bird, A., Oddou, G. R., \& Maznevski, M. L. (2008). Global leadership: Research, practice, and development. Routledge.

Michailova, S., Piekkari, R., Storgaard, M., \& Tienari, J. (2017). Rethinking ethnocentrism in international business research. Global Strategy Journal, 7(4), 335353.

Moon, T. (2010). Emotional intelligence correlates of the four-factor model of cultural intelligence. Journal of Managerial Psychology, 25(8), 876-898.

Neter, J., Wasserman, W., \& Kutner, M. H. (1985). Applied linear statistical models (2nd ed.). Irwin.

Neuliep, J. W. (2002). Assessing the reliability and validity of the generalized ethnocentrism scale. Journal of Intercultural Communication Research, 31(4), 201215.

Neuliep, J. W., Hintz, S. M., \& McCroskey, J. C. (2005). The influence of ethnocentrism in organizational contexts: Perceptions of interviewee and managerial attractiveness, credibility, and effectiveness. Communication Quarterly, 53(2), 41-56.

Neuliep, J. W., \& McCroskey, J. C. (1997). The development of a US and generalized ethnocentrism scale. Communication Research Reports, 14(4), 385398.

Nunnally, J. C. \& Bernstein, I. H. (1994) Psychometric Theory, McGraw-Hill.

Podsakoff, P. M., MacKenzie, S. B., Lee, J. Y., \& Podsakoff, N. P. (2003). Common method biases in behavioral research: A critical review of the literature and recommended remedies. Journal of Applied Psychology, 88(5), 879-884.

Podsakoff, P. M., \& Organ, D. W. (1986). Self-reports in organizational research: Problems and prospects. Journal of Management, 12(4), 531-544.

Reiche, B. S., Harzing, A. W., \& Kraimer, M. L. (2009). The role of international assignees' social capital in creating inter-unit intellectual capital: A cross-level model. Journal of International Business Studies, 40, 509-526.

Rockstuhl, T., Seiler, S., Ang, S., Van Dyne, L., \& Annen, H. (2011). Beyond general intelligence (IQ), and emotional intelligence (EQ): The role of cultural intelligence (CQ) on cross-border leadership effectiveness in a globalized world. Journal of Social Issues, 67(4), 825-840.

Rozell, E. J., Pettijohn, C. E., \& Parker, R. S. (2006) Emotional intelligence and dispositional affectivity as predictors of performance in salespeople. Journal of Marketing Theory and Practice, 14(2), 113-124.

Sabuhari, R., Sudiro, A., Irawanto, D., \& Rahayu, M. (2020). The effects of human resource flexibility, employee competency, organizational culture adaptation and job satisfaction on employee performance. Management Science Letters, 10(8), 1775-1786.

Salovey, P. \& Mayer, J. D. (1990). Emotional intelligence. Imagination, Cognition and Personality, 9(3), 185-211.

Shaffer, M. A., Harrison, D. A., Gregersen, H., Black, J. S., \& Ferzandi, L. A. (2006). You can take it with you: Individual differences and expatriate effectiveness. Journal of Applied Psychology, 91(1), 109-125.

Sumner, W. G. (1906). Folkways. Ginn.

Suutari V., Brewster C., \& Tornikoski C. (2013). The careers of self-initiated expatriates. In V. Vaiman, \& A. Haslberger (Eds.), Talent management of self-initiated expatriates (pp. 159-180). Palgrave Macmillan.

Takeuchi, R., Yun, S., \& Russell, J. E. A. (2002). Antecedents and consequences of the perceived adjustment of Japanese expatriates in the USA. International Journal of Human Resource Management, 13, 1224-1244.

Tay, L. \& Jebb, A. (2017). Scale Development. In S. Rogelberg (Ed.), The SAGE encyclopedia of industrial and organizational psychology (2nd ed.). Sage.

Templer, K. J. (2010). Personal attributes of expatriate managers, subordinate ethnocentrism, and expatriate success: A host-country perspective. The International Journal of Human Resource Management, 21(10), 1754-1768.

Templer, K. J., Tay, C., \& Chandrasekar, N. A. (2006). Motivational cultural intelligence, realistic job preview, realistic living conditions preview, and cross-cultural adjustment. Group \& Organization Management, 31(1), 154-173.

Thomas, D. C., Elron, R., Stahl, G., Ekelund, B. Z., Ravlin, E. C., Cerdin, J. L., ... Lazarova, M. B. (2008). Cultural intelligence: Domain and assessment. International Journal of Cross-Cultural Management, 8(2), 123-143. 
Thomas, D. C., Liao, Y., Aycan, Z., Cerdin, J.L., Pekerti, A. A., Ravlin, E. C., ... Van de Vijver, F. (2015). Cultural intelligence: A theory-based, short form measure. Journal of International Business Studies, 46(9), 1099-1118.

Thomas, K. M. (1996). Psychological privilege and ethnocentrism as barriers to cross-cultural adjustment and effective intercultural interactions. The Leadership Quarterly, 7(2), 215-228.

Van Bakel, M., Gerritsen, M., \& Van Oudenhoven, J. P. (2014). Impact of a local host on the intercultural competence of expatriates. International Journal of Human Resource Management, 25(14), 2050-2067.

Van Dyne, L., Ang, S., \& Koh, C. (2008). Development and validation of the CQS: The cultural intelligence scale. In S. Ang, \& L. Van Dyne (Eds.), Handbook of Cultural Intelligence: Theory, Measurement, and Applications (pp. 16-38). Sharpe.

Van Rooy, D. L. \& Viswesvaran, C. (2004). Emotional intelligence: A meta-analytic investigation of predictive validity and nomological net. Journal of Vocational Behavior, 65(1), 71-95.

Ward, C., Fischer, R., Lam, F. S. Z., \& Hall, L. (2009). The convergent, discriminant, and incremental validity of scores on a self-report measure of cultural intelligence. Educational and Psychological Measurement, 69(1), 85-105.

Ward, C., Wilson, J., \& Fischer, R. (2011). Assessing the predictive validity of cultural intelligence over time. Personality and Individual Differences, 51(2), 138142.

Whitman, D. S., Van Rooy, D. L., Viswesvaran, C., \& Kraus, E. (2009). Testing the second-order factor structure and measurement equivalence of the Wong and Law emotional intelligence scale across gender and ethnicity. Educational and Psychological Measurement, 69(6), 1059-1074

Wooldridge, J. M. (2009). Introductory econometrics: A modern approach (4th ed.). South-Western CENGAGE Learning.

Wong, C., \& Law, K. S. (2002). The effect of leader and follower emotional intelligence on performance and attitude: An exploratory study. The Leadership Quarterly, 13, 243-274.

Zeira, Y., \& Banai, M. (1981). Attitudes of host-country organizations toward MNCs' staffing policies: A cross-country and cross-industry analysis. Management International Review, 21(2), 38-47. 